\title{
RESENHA DE MACHADO DE ASSIS: INTÉRPRETE DA SOCIEDADE BRASILEIRA, ORGANIZADO POR JURACY ASSMANN SARAIVA E REGINA ZILBERMAN
}

\section{REVIEW OF MACHADO DE ASSIS: INTÉRPRETE DA SOCIEDADE BRASILEIRA, EDITED BY JURACY ASSMANN SARAIVA E REGINA ZILBERMAN}

SARAIVA, Juracy Assmann; ZILBERMAN, Regina (Org.). Machado de Assis: intérprete da sociedade brasileira. Porto Alegre: Zouk, 2020.

\section{Luiz Mauricio Azevedo da Silva}

Universidade de São Paulo

São Paulo, São Paulo, Brasil

Publicado em 2020, Machado de Assis: intérprete da sociedade brasileira é uma reunião de textos críticos, com organização de Regina Zilberman e Juracy Assmann Saraiva, e apresentação assinada por Roberto Acízelo de Souza, trazida ao público pela editora gaúcha Zouk. O conjunto é uma construção bem-sucedida de artefato teórico que não se furta a tomar de empréstimo a dicção crítica do autor que pretende analisar. Cada artigo exposto representa um tipo de postulação pertinente de uma fração de obra machadiana a ser considerada a mais relevante. Trata-se do cumprimento de uma parte significativa do trabalho da crítica, que é justamente recolher aquilo que a obra literária tem de específico, e conseguir, à luz de algum apoio teórico, expor as razões dessa validade. Cada um dos textos reunidos na coletânea consegue, com competência acadêmica, apresentar um Machado de Assis diferente, extraído não somente do universo restrito das obras, mas do vasto conjunto obra-mais-contexto-histórico. Essa perspectiva analítica acertada multiplica, ao longo do tempo, sua materialização. É ela a força motora do binômio literatura/sociedade, de Candido; realidade objetiva/teoria, de Marx; 
e materialismo/cultura, de Williams. Grosso modo, ela representa a razão pela qual nos interessa tanto, em 2020, ler obras produzidas há séculos. Fosse somente a experiência fetichista da viagem simbólica a uma outra época e a literatura desses vultos já se justificaria. Mas, no caso de Machado de Assis, a questão parece ser justamente o contrário. A discussão ocorre, então, não apenas pelo que Machado disse, mas pelo que deixou de dizer: no modo como ele não falou da escravidão, no sentido oculto daquilo que ele não nos contou sobre o comportamento de Capitu. Há valor nas sombras. Os múltiplos Machados ressurgem nessa obra como desfile das contradições humanas de um indivíduo em sua época, com o fornecimento de importantes ferramentas para a interpretação de razões e vontades.

Os autores e autoras que aceitaram o desafio de revistar os códigos machadianos conseguem escapar dos clichês teóricos e interditar a tentação de repetir a ladainha de adjetivos de adulação ao mistério, que condenaram diversos textos sobre Machado ao uso obrigatório das palavras oblíquo, indecifrável, opaco.

O conjunto de textos revela uma proposição que se projeta para além do mero compromisso crítico com o texto machadiano - o que por si só já seria imenso - e alcança a ambiciosa figuração de uma reinterpretação do Brasil a partir do olhar do autor. Juntos, os trabalhos reunidos na publicação operam como um artefato teórico destinado a revisar o que resta dos efeitos sociais da obra de Machado de Assis. Os ensaios representam tanto o resultado produtivo do grupo de pesquisa "Ficção de Machado de Assis: sistema poético e contexto" (registrado no CNPq), como o esforço de internacionalização e diversificação do debate por parte das organizadoras, que resulta no amplo espectro de participantes, que vão desde pesquisadores de dez prestigiadas instituições de ensino superior ao redor do mundo (UFRGS, UFC, UFF, UFRJ, Unesp, UnB, Feevale, Yale, Harvard, Purdue) a membros de institutos federais (IFSC) e de instituições de educação básica (Colégio Israelita Brasileiro) - o que garante inequívoca diversidade técnica e perspectiva ao volume.

Dos artigos publicados destacam-se: "O gesto na ficção machadiana”, de Kenneth David Jackson; “Teatralidade: diálogo entre arte e vida”, de Juracy Assmann Saraiva; "Duas Floras: de Machado a Erico Veríssimo”, de Maria da Glória Bordini; "Medalhão: profissão sem trabalho", de Antonio Marcos Vieira Sanseverino; "Um código de honra feminino: 'A senhora do Galvão”, de Paul Dixon; "Machado de Assis e a poesia de Faustino Xavier de Novaes", de Regina Zilberman; "Machado de Assis: relações com o mundo editorial”, de Lúcia Granja; e "A crônica machadiana: problemas de interpretação, temas de 
pesquisa”, de Sidney Chalhoub. A abordagem específica de cada um desses artigos não deve, todavia, sugerir que os demais textos que compõem a obra e que eventualmente não foram contemplados no escopo desta resenha importam menos. O critério de seleção utilizado aqui diz respeito à necessidade de indicar com clareza os blocos de tensão que podem servir como exemplos daquilo que os leitores e as leitoras encontrarão no contato com o livro analisado.

Em “O gesto na ficção machadiana”, Kenneth David Jackson oferece uma investigação sobre os usos do gesto na confecção da prosa machadiana, na qual, segundo ele, o gesto possui centralidade. A função semiótica do gesto ganha relevância maior se considerarmos que, na obra machadiana, há sempre algo em lugar de algo, em uma longa, lúdica e psicanalítica luta pelo controle da dinâmica dos poderes simbólicos. Essa potência apontada por Jackson é uma chave de leitura não apenas eficiente para a obra do próprio Machado de Assis, como também para toda a literatura afro-brasileira que vai - de um modo consciente ou inconsciente - girar em torno dos jogos mentais que a literatura do escritor carioca edificou.

Em “Teatralidade: diálogo entre arte e vida”, Juracy Assmann Saraiva aborda não apenas as relações de Machado com o teatro, como também - e talvez principalmente - de que maneira os princípios da representação teatral ultrapassam as fronteiras dos gêneros narrativos e podem se tornar, a depender da capacidade crítica de quem escreve, uma metáfora sobre a conduta social dos autores, o que, por vezes, explica a claudicância do comportamento ético das figuras históricas que aprendemos a admirar.

Já Maria da Glória Bordini enfrenta o desafio comparativo, propondo uma régua estética que aproxima Erico Verissimo de Machado de Assis, observando o processo de construção das personagens femininas na obra desses autores. Bordini não se furta a apontar certa tensão de gênero nos dois autores que, por flacidez intelectual, má-fé ou machismo estrutural, a crítica literária brasileira se recusou a reconhecer em sucessivos e renitentes momentos. Essas tensões - que talvez em Machado tenham sido abordadas fortemente por Helen Caldwell, e em Verissimo pela própria Bordini - não representam apenas chaves de leitura marginais, e sim possíveis caminhos ainda pouco explorados em um campo que por vezes se ressente de um empanturramento de soluções consideradas repetidas e inócuas.

Paul Dixon segue em tom semelhante ao de Bordini, mas volta seu olhar para as raízes da masculinidade nacional, porque há algo de falha narcísica no modo como a identidade do indivíduo masculino parece estar sempre em risco, 
quando em presença de uma representação feminina. Em certo sentido, esses dois artigos atacam o mesmo problema por locais diferentes: enquanto Bordini aponta as falhas da crítica, Dixon investe no desmonte do espetáculo da masculinidade na crítica machadiana, colaborando, com marteladas vigorosas do outro lado da edificação, e ajudando Bordini a derrubar o que pode ser considerado parte da miopia de gênero na crítica machadiana.

Antonio Marcos Vieira Sanseverino por sua vez acredita em uma abordagem adorniana, de caráter psicanalítico, que funde certos arquétipos da obra machadiana com as janelas abertas para a compreensão do funcionamento social do capitalismo brasileiro. Sanseverino, de certo modo, propõe aqui uma releitura de Machado de Assis como uma encarnação daquilo que já se convencionou um DNA barroco do Brasil, e que em Machado aparece como mais um elemento de um realismo complexo - que não se limita a descrever aquilo que lhe deu origem, tampouco rejeita a oportunidade de enxertar na descrição os elementos que a dificultam.

Já Zilberman se dedica ao papel de Machado de Assis como articulador cultural, em especial como preparador de originais de um volume de poemas de Faustino Xavier de Novaes. Zilberman supõe que o título do livro - Poesias póstumas - tenha origem no fato de o autor ter falecido em 1869, ano anterior à publicação da obra. Não se trata de um chiste ou de uma referência banal. Durante todo o texto da autora corre, em uma subjacência potente, a sugestão de que o trabalho de construção literária de uma obra está ligado não apenas ao texto que deu origem a ela, mas ao tipo de literatura e de conexão com a cultura do livro que ele pretende disseminar ou, nos melhores casos, fortalecer. A dicção sofisticada da autora emula a mesma atmosfera irônica da escrita de Machado e procura fazer com que sua análise se pareça - em formato e teor com o tipo de análise de conjuntura que o autor de Memórias póstumas de Brás Cubas gostava de propor aos leitores. Mistura-se o estilo da analista ao formato do artefato analisado, em uma crítica que se alimenta das intermitências narrativas e de vazios semióticos à espera de sentido, de fenômenos que tantos acreditam ser um complicador para compreender a obra machadiana, mas que possivelmente sejam seu maior sabor.

O papel de Machado como personalidade cultural vai interessar também Lúcia Granja, cujo foco é recuperar as feições da relação de Machado de Assis com o mundo editorial. De certa forma, os artigos de Zilberman e de Granja parecem funcionar como um par, no qual aparece um Machado consciente das repercussões políticas das decisões editoriais. 
Por fim, destaca-se o texto de Sidney Chalhoub - "A crônica machadiana: problemas de interpretação, temas de pesquisa” -, uma impressionante demonstração pública de erudição e de disposição de combater o tártaro dos estudos machadianos: a tendência a fazer do autor um caso encerrado, sobre quem a crítica já teria dito tudo. O texto é também o que mais tensiona a forma ensaísta. Nesse caso, trata-se de um ensaio em que as referências bibliográficas não trabalham a serviço de quem lê, mas em direção a um argumento que parece sustentar a existência de um certo mal-estar constante oriundo da consciência de que os objetos se alimentam do esforço dos analistas em compreendê-los, ficando cada vez maiores à medida que aumenta nossa capacidade de abordá-los.

A diagramação competente e as escolhas tipográficas adequadas que abundam no miolo do livro contrastam com a capa inexplicavelmente anacrônica, que reverencia uma falsificação imagética da figura de Machado de Assis. Nela aparece uma figura esbranquiçada, retratada em traço artístico, que sugere simular um desprendimento da publicação em relação ao histórico de más interpretações representativas da imagem do escritor. Isso fornece, a quem lê, a sensação de que houve uma opção pela fuga do incandescente debate sobre a efetivação de um apagamento, de filiação ideológica eugenista, que foi a construção de um processo histórico-cultural que violentou a verdade fenotípica do indivíduo Machado de Assis. O fato de esses deslizamentos simbólicos terem acontecido durante décadas, em épocas de vergonha, ingenuidade cínica e incapacidade crítica é algo perfeitamente aceitável. Contudo, a evidência constrangedora de que esses elementos habitam, ainda hoje, o seio de uma era de afirmação, enfrentamento e rigor intelectual constitui uma tensão benjaminiana inesperada, na qual o miolo será um documento de civilização e a capa será um testemunho de barbárie. A imagem estática de Machado contrasta com um conteúdo de diálogos de grande valor crítico e faz - perigosamente - sugerir que o livro se opõe ao processo de ressemantização da fenotipia do autor.

Para além desse ruidoso engano, por todos esses elementos elencados aqui, conclui-se que essa é uma publicação da qual só se pode lamentar a capa, o que é infortúnio menor considerando que pode ser coberta facilmente no mergulho profundo que seu miolo - parte fundamental de qualquer publicação - oferece a quem lê. 
Machado de Assis em Linha - Universidade de São Paulo

http://machadodeassis.fflch.usp.br - Resenha

\section{Referências}

BORDINI, Mária da Glória. Duas Floras: de Machado a Erico Veríssimo. In: SARAIVA, Juracy Assmann; ZILBERMAN, Regina (Org.). Machado de Assis: intérprete da sociedade brasileira. Porto Alegre: Zouk, 2020. p. 131-140.

CHALHOUB, Sidney. A crônica machadiana: problemas de interpretação, temas de pesquisa. In: SARAIVA, Juracy Assmann; ZILBERMAN, Regina (Org.). Machado de Assis: intérprete da sociedade brasileira. Porto Alegre: Zouk, 2020. p. 195-216.

DIXON, Paul. Um código de honra feminino: "A senhora do Galvão". In: SARAIVA, Juracy Assmann; ZILBERMAN, Regina (Org.). Machado de Assis: intérprete da sociedade brasileira. Porto Alegre: Zouk, 2020. p. 185-194.

GRANJA, Lúcia. Machado de Assis: relações com o mundo editorial. In: SARAIVA, Juracy Assmann; ZILBERMAN, Regina (Org.). Machado de Assis: intérprete da sociedade brasileira. Porto Alegre: Zouk, 2020. p. 251-260.

JACKSON, Kenneth David. O gesto na ficção machadiana. In: SARAIVA, Juracy Assmann; ZILBERMAN, Regina (Org.). Machado de Assis: intérprete da sociedade brasileira. Porto Alegre: Zouk, 2020. p. 11-24.

SANSEVERINO, Antonio Marcos Vieira. Medalhão: profissão sem trabalho. In: SARAIVA, Juracy Assmann; ZILBERMAN, Regina (Org.). Machado de Assis: intérprete da sociedade brasileira. Porto Alegre: Zouk, 2020. p. 157-174.

SARAIVA, Juracy Assmann. Teatralidade: diálogo entre arte e vida. In: ZILBERMAN, Regina (Org.). Machado de Assis: intérprete da sociedade brasileira. Porto Alegre: Zouk, 2020. p. 25-44.

ZILBERMAN, Regina. Machado de Assis e a poesia de Faustino Xavier de Novaes. In: SARAIVA, Juracy Assmann; (Org.). Machado de Assis: intérprete da sociedade brasileira. Porto Alegre: Zouk, 2020. p. 231-250.

LUIZ MAURÍCIO AZEVEDO DA SILVA é doutor em Teoria e História Literária, pela Unicamp, e pós-doutorando no Departamento de Letras Clássicas e Vernáculas da USP. Atualmente é professor-convidado do curso de Especialização em Literatura Brasileira da UFRGS. Em 2015, ocupou uma posição de Visiting Researcher na Rutgers University, onde realizou pesquisa sob supervisão de Barbara Foley. É autor de A toupeira invisível: marxismo negro \& cultura antimarxista em Ralph Ellison. Em 2019, seu livro Pequeno espólio do mal foi indicado ao Prêmio Açorianos, na categoria narrativa longa. Seus interesses são: a literatura afro-americana do século XX, o materialismo histórico, o modernismo negro e a produção literária afro-brasileira. (D) https://orcid.org/0000-0002-6813-1299

E-mail:mauricioazevedomeister@gmail.com 